$\overline{\text { Note }}$

\title{
The Rapid Detection of Salmonella from Food Samples By Loop-Mediated Isothermal Amplification (LAMP)
}

\author{
SHIGEKO UEDA* AND YOSHIHIRO KUWABARA
}

\author{
Laboratory of Hygiene, Kagawa Nutrition University \\ 3-9-21, Chiyoda, Sakado-shi, Saitama 350-0214, Japan
}

Received 18 August, 2008/Accepted 7 March, 2009

\begin{abstract}
Loop-mediated isothermal amplification (LAMP) assay was applied to the detection of Salmonella in food and human materials. It was possible for the assay to detect Salmonella within $60 \mathrm{~min}$. All of 54 serovars of Salmonella tested were amplified, but all bacteria tested other than Salmonella were not. The LAMP assay could detect $10^{2} \mathrm{cfu} / \mathrm{ml}$ levels of Salmonella. The specificity was similar to that of a PCR assay, but the sensitivity of LAMP was considered to be greater. Thus, the LAMP assay was confirmed to be a rapid, specific and sensitive detection method for Salmonella.
\end{abstract}

Key words : Salmonella/LAMP/PCR/Food.

Salmonella is one of the most common causal agents of foodborne infections in Japan. Because Salmonella contamination levels in foods are generally low compared to clinical specimens, it has been necessary to use the culture enrichment method to test food samples and more than three days are required for its detection and identification (Hara-Kudo et al., 2005). For public health and the food industry, rapid, sensitive and specific methods to detect Salmonella in food are required. Of several molecular genetic methods, the polymerase chain reaction (PCR) assay is the most widely used for specific amplification of a target gene, and it has been reported to be able to rapidly detect target pathogens (Bej et al., 1990; Chiu and Ou, 1996; Golsteyn-Thomas et al., 1991). Recently, LAMP that amplifies DNA with high specificity, efficiency and rapidity under isothermal conditions has been developed as a novel nucleic acid amplification method (Enosawa et al.,2003; Mori et al.,2001; Notomi et al.,2000). This method relies on an auto-cycling strand displacement DNA synthesis performed by the Bst polymerase large fragment, and is different from PCR in that four or six different primers perform the amplification of the target gene,

*Corresponding author. Tel/Fax : +81-49-282-3717. and the amplification uses a constant temperature between 60 and $65^{\circ} \mathrm{C}$ for about 60 min. The amplification products have variously sized structures consisting of alternate inverted repeats of the target sequence on the same strand in large amounts. The target gene is simply detected by the increase in the turbidity, as the reaction produces the precipitate correlated with the amount of target DNA synthesized. In this study, we evaluated the specificity and sensitivity of a LAMP assay for the rapid detection of Salmonella.

The specificity of the LAMP assay was tested by using 54 serovars of Salmonella spp., 4 gramnegative species including Citrobacter freundii, Escherichia coli, Yersinia enterocolitica and Vibrio parahaemolyticus, and 6 gram-positive species including Staphylococcus aureus, Bacillus cereus, Bacillus subtilis, Bacillus licheniformis, Clostridium botulinum, Clostridium perfringens and Listeria monocytogenes. Salmonella spp. and $C$. freundii were cultured on DHL agar medium (Nissui). E. coli O157 was cultured on Rainbow agar medium (Biolog). Other E. coli serovars and strains were cultured on EMB agar medium (Nissui). Y. enterocolitica was cultured on CIN agar medium (Oxoid), $V$. parahaemolyticus on TCBS agar medium (Nissui), L. monocytogenes on Oxford base agar medium 
(Nissui), B. cereus on NGKG agar medium (Nissui), and $C$. botulinum and $C$. perfringens were on $\mathrm{CW}$ agar medium (Eiken). After each strain was incubated at $37^{\circ} \mathrm{C}$ for $18 \mathrm{~h}$, a typical colony on the selective agar medium was used for the LAMP and PCR assays. To evaluate the sensitivity of the LAMP assay, S. Enteritidis was inoculated into liquid samples and $10 \%$ suspensions of solid samples at concentrations of $10^{\circ}-10^{3} \mathrm{cfu} / \mathrm{ml}$. The food samples were egg, milk, yogurt, omelette, hamburger, raw pork, beef and chicken, roast beef, lettuce, vegetable salad, watermelon, apple juice, spinach saute and cake. Also, the blood and faeces of a healthy human subject were used. The enrichment media containing Brain heart infusion broth (BBL), Trypticase broth (BBL) and EEM broth (Nissui) were utilized as references.

The LAMP reaction was performed using a Loopamp DNA kit (Eiken Chem. Co., Ltd.). A colony on the selective agar media or $50 \mu \mathrm{I}$ of the sample suspension was added to $50 \mu \mathrm{I}$ of the extraction solution (pH12.5) (Eiken Chem. Co., Ltd.) in a microcentrifuge tube and heated at $100^{\circ} \mathrm{C}$ for $5 \mathrm{~min}$ to extract DNA. The samples were centrifuged at $2,000 \mathrm{~g}$ for $1 \mathrm{~min}$, and the supernatant was transferred to a new microcentrifuge tube and used as the template DNA solution for the LAMP assay. A $20 \mu$ I of 'Reaction Mix. Sal' containing the primers for Salmonella detection and $1 \mu \mathrm{l}$ of Bst DNA polymerase were mixed in another tube. A $20 \mu \mathrm{I}$ aliquot of the mixture was transferred and $5 \mu \mathrm{l}$ of the template DNA solution was added to a reaction tube. The reaction components were mixed in the tube, incubated at $65^{\circ} \mathrm{C}$ for $60 \mathrm{~min}$ and then heated to $80^{\circ} \mathrm{C}$ for 2 min to terminate the reaction. Salmonella DNA preparation extracted from $S$. Enteritidis was used as a positive control and the DNA-omitted reaction mixture was used as a negative control. The amplification of the gene was confirmed by real-time monitoring of the increase of turbidity produced by magnesium pyrophosphate during the reaction (Mori et al., 2001) by using a loopamp realtime tubidimeter (Teramecs, Kyoto), which sequentially measured the absorbance of the reaction mixture at $650 \mathrm{~nm}$. The LAMP assay was able to detect Salmonella within $60 \mathrm{~min}$.

PCR was performed with a kit for detection of Salmonella invA gene (Takara). The PCR mixture $(100 \mu \mathrm{l})$ in a reaction tube contained $10 \mu \mathrm{I}$ of template DNA, $8 \mu \mathrm{l}$ of $2.5 \mathrm{mM}$ dNTP mixture, $1 \mu \mathrm{l}$ of primer-1, $1 \mu \mathrm{I}$ of primer-2, $2.5 \mathrm{U}$ of Taq DNA polymerase, $10 \mu \mathrm{I}$ of $10 \times$ PCR buffer and $69.5 \mu \mathrm{I}$ of double-distilled water. The PCR reaction was performed with a DNA thermal cycler (Biocraft, type QTP-1) and was subjected to 35 cycles consisting of $1 \mathrm{~min}$ at $94^{\circ} \mathrm{C}$ for denaturation, $1 \mathrm{~min}$ at $55^{\circ} \mathrm{C}$ for annealing and $1 \mathrm{~min}$ at $72^{\circ} \mathrm{C}$ for extension. A $10 \mu \mathrm{I}$ aliquot of the PCR products was subjected to electrophoresis on a $2 \%(\mathrm{w} / \mathrm{V})$ agarose (Sigma) gel in Trisacetate-EDTA buffer (Ueda et al., 2000).

The specificity of LAMP was examined by carrying out reactions with DNA from various Salmonella spp. and other gram-negative and gram-positive bacteria. $S$. Enteritidis and $S$. Typhimurium gave positive reactions, but bacterial strains other than Salmonella did not (Table 1). Furthermore, it was confirmed that all of 54 serovars of Salmonella were confirmed to give positive results, and other gram-negative bacteria gave negative results in the LAMP assay (Table 2). The PCR method also showed positive results for Salmonella, but showed negative results for all other

TABLE 1. Specificity of the LAMP method for the detection of Salmonella spp.

\begin{tabular}{|c|c|}
\hline Bacterial species/serovar/strain & Result \\
\hline Salmonella Enteritidis & + \\
\hline Salmonella Typhimurium & + \\
\hline \multicolumn{2}{|l|}{ Escherichia coli } \\
\hline 0127:H21 (EPEC $\left.{ }^{1)}\right)$ & - \\
\hline O124:HNM (EIEC $\left.{ }^{2}\right)$ & - \\
\hline ST and LT producer $\left(E^{2} E^{3)}\right)$ & - \\
\hline 0157:H7 (VT1 and VT2 producer) (EHEC $\left.{ }^{4)}\right)$ & - \\
\hline 0157:H7 (VT2 producer) (EHEC $\left.{ }^{4)}\right)$ & - \\
\hline 0157:H7 (non-VT producer) (ATCC43888) & - \\
\hline 0111:NM (VT1 and VT2 producer) (EHEC ${ }^{4)}$ ) & - \\
\hline O26:NM (VT1 and VT2 producer) (EHEC $\left.{ }^{4)}\right)$ & - \\
\hline strain V517 & - \\
\hline strain IFO3301 & - \\
\hline type | from food & - \\
\hline \multicolumn{2}{|l|}{ Citrobacter freundii } \\
\hline strain 1 & - \\
\hline strain 2 & - \\
\hline strain 3 & - \\
\hline strain 4 & - \\
\hline strain 5 & - \\
\hline strain 6 & - \\
\hline strain 7 & - \\
\hline strain 8 & - \\
\hline strain 9 & - \\
\hline strain 10 & - \\
\hline Yersinia enterocolitica & - \\
\hline Vibrio parahaemolyticus & - \\
\hline Staphylococcus aureus (8 strains) & - \\
\hline Bacillus cereus (3 strains) & - \\
\hline Bacillus subtilis & - \\
\hline Bacillus licheniformis (2 strains) & - \\
\hline Clostridium botulinum & - \\
\hline Clostridium perfringens & - \\
\hline Listeria monocytogenes & - \\
\hline $\begin{array}{l}\text { 1) Enteropathogenic E. coli; 2) Enteroi } \\
\text { 3) Enterotoxigenic E. coli; 4) Enterohe }\end{array}$ & $\begin{array}{l}\text { coli; } \\
\text { E. coli }\end{array}$ \\
\hline
\end{tabular}


TABLE 2. Species specificity of LAMP and PCR method for Salmonella serovars.

\begin{tabular}{|c|c|c|c|c|c|}
\hline \multirow{2}{*}{$\begin{array}{c}\text { Salmonella } \\
\text { species/serovar }\end{array}$} & \multicolumn{2}{|c|}{ Result } & \multirow{2}{*}{$\begin{array}{c}\text { Salmonella } \\
\text { species/serovar }\end{array}$} & \multicolumn{2}{|c|}{ Result } \\
\hline & LAMP & PCR & & LAMP & PCR \\
\hline Agona & + & + & Montevideo & + & + \\
\hline Anatum & + & + & Muenchen & + & + \\
\hline Bareilly & + & + & Muenster & + & + \\
\hline Blockley & + & + & Nagoya & + & + \\
\hline Braenderup & + & + & Narashino & + & + \\
\hline Brandenburg & + & + & Newport & + & + \\
\hline Cerro & + & + & Ohio & + & + \\
\hline Chailey & + & + & Oranieburg & + & + \\
\hline Chester & + & + & Othmarschen & + & + \\
\hline Chincol & + & + & Paratyphi A & + & + \\
\hline Derby & + & + & Paratyphi B & + & + \\
\hline Djugu & + & + & Potsdam & + & + \\
\hline Dublin & + & + & Saintpaul & + & + \\
\hline Enteritidis & + & + & Sandow & + & + \\
\hline Hadar & + & + & Schwarzengrund & + & + \\
\hline Haifa & + & + & Senftenberg & + & + \\
\hline Hartford & + & + & Singapore & + & + \\
\hline Heiderberg & + & + & Stanley & + & + \\
\hline Holcomb & + & + & Stanleyville & + & + \\
\hline Infantis & + & + & Tennessee & + & + \\
\hline Isangi & + & + & Thompson & + & + \\
\hline Litchfield & + & + & Typhi & + & + \\
\hline Liverpool & + & + & Typhimurium & + & + \\
\hline Livingstone & + & + & Uppsala & + & + \\
\hline London & + & + & Virchow & + & + \\
\hline Manhatten & + & + & Weltevreden & + & + \\
\hline Mbandaka & + & + & Zanzibar & + & + \\
\hline
\end{tabular}

bacteria other than Salmonella (Table 2). Thus, the specificity of the LAMP assay was as high as that for PCR, as described by Hara-Kudo et al. (2005). Also, the LAMP assay was shown to be able to detect many pathogenic microorganisms specifically by using the primers designed for the respective target genes (Furuhata et al., 2005; Horisaka et al., 2004; Yoda et al., 2007).

The sensitivity of the LAMP assay for Salmonella was examined by determining the detection limit from 3 different liquid media and 10\% suspensions of different food samples and human materials inoculated with various levels of Salmonella Enteritidis cells. Hara-Kudo et al. (2005) described the detection limit of LAMP assay as 370 to 434 cells/ml of the concentration. In this study, the LAMP assay was able to detect the target gene from all food and human materials contaminated with $10^{2} \mathrm{cfu} / \mathrm{ml}$ of Salmonella. However, it was suggested that even levels less than $10^{2} \mathrm{cfu} / \mathrm{ml}$ were detectable depending on the material suspensions. Ueda et al. (2000) reported that the detection limit of PCR was $10^{3}$ to $10^{5} \mathrm{cfu} / \mathrm{ml}$ of Salmonella cells. Furthermore, if the Salmonella contamination level in the sample was estimated to be below the detection limit, it was found to be detected by using the appropriate enrichment preculuture for several hours. Horisaka et al. (2004) also described that LAMP was 100 times more sensitive than PCR. Notomi et al. (2000) reported that the sensitivity of LAMP was not influenced by the copresence of nontarget DNA in samples and Enosawa et al. (2003) reported that LAMP was not inhibited by blood serum and plasma heparin, which are known to inhibit PCR.

This study demonstrated that the LAMP assay was effective in detecting Salmonella rapidly, specifically and with high sensitivity.

\section{REFERENCES}

Bej, A. K., Steffan, R. J., and DiCesare, J. (1990) Detection of coliform bacteria in water by polymerase chain reaction and gene probes. Appl. Environ. Microbiol., 56, 307314.

Chiu, C-H., and Ou, J. T. (1996) Rapid identification of Salmonella serovars in feces by specific detection of virulence genes, invA and spvC, by an enrichment broth culture-multiplex combination assay. J. Clin. Microbiol., 34, 2619-2622.

Enosawa, M., Kageyama, S., Sawai, K., Watanabe, K., Notomi, T., Onoe, S., Mori, Y., and Yokomizo, Y. (2003) Use of loop-mediated isothermal amplification of the IS900 sequence for rapid detection of cultured Mycobacterium avium subsp. paratuberculosis. J. Clin. Microbiol., 41, 4359-4365.

Furuhata, K., Annaka, T., Ikedo, M., Fukuyama, M., and Yoshida, S. (2005) Coparison of loop-mediated isothermal amplification (LAMP) and conventional culture for the detection of Legionella species in hot spring water samples in Japan. Biocontrol Sci., 10, 117-120.

Golsteyn-Thomas, E.J., King, R.K., and Burchak. J. (1991) Sensitive and specific detection of Listeria monocytogenes in ground beef with the polymerase chain reaction. Appl. Environ. Microbiol., 57, 2576-2580.

Hara-Kudo, Y., Yoshino, M., Kojima, T., and IKedo, M. (2005) Loop-mediated isothermal amplification for the rapid detection of Salmonella. FEMS Microbiol. Lett., 253, 155-161.

Horisaka, T., Fujita, K., Iwata, T., Nakadai, A., Okatani, AT., Horikita, T., Taniguchi, T., Honda, E., Yokomizo, Y., and Hayashidani, H. (2004) Sensitive and specific detection of Yersinia pseudotuberculosis by loop-mediated isothermal amplification. J. Clin. Microbiol., 42, 5349-5352.

Mori, Y., Nagamine, K., Tomita, N., and Notomi, T. (2001) Detection of loop-mediated isothermal amplification reaction by turbidity derived from magnesium pyrophosphate formation. Biochem. Biophys. Res. Commun., 289, 150154.

Notomi, T., Okayama, H., Masubuchi, H., Yonekawa, T., Watanabe, K., Amino, N., and Hase, T. (2000) Loopmediated isothermal amplification of DNA. Nucleic acids Res., 28, e63.

Ueda, S., Umesako, S., Mineno, J., and Kuwabara, Y. (2000) The magnetic immuno polymerase chain reaction assay for detection of Salmonella from and fecal samples. Biocontrol Sci., 5, 25-32.

Yoda, T., Suzuki, Y., Yamazaki, K., Sakon, N., Kanki, M., 
S. UEDA ET AL.

Aoyama, I., and Tsukamoto, T. (2007) Evaluation and application of reverse transcription loop-mediated iso-

thermal amplification for detection of Noroviruses. $J$. Med. Virol., 79, 326-334. 